\title{
Research on the Educational Technology Training Model Establishment for University Teachers in Information Environment
}

\author{
Fushan Bao ${ }^{1,}$, Xiong Ling ${ }^{2, b}$ \\ ${ }^{1}$ Department of Media, Huhhot Nationality College, Huhhot City, Inner Mongolia, 010051 \\ ${ }^{2}$ Hohhot Vocational College, Huhhot City, Inner Mongolia, 010051
}

Keywords: educational technology training; model establishment; university teachers; information environment

\begin{abstract}
The information literacy of teachers in the 21st century, especially the application of modern educational technology, is an essential quality for teachers. Through the investigation and study on the application skills of some local colleges and universities' educational technology, this paper finds that the university teachers lack the correct understanding of the educational technology theory and application in the teaching process. The ability of applying the educational technology to assist teaching in teaching is extremely limited. The reason is that there is no effective training mode to improve their educational and technical literacy, and the training mode has not kept pace with the development of China's education informatization. Therefore, this paper proposes some new ideas for the training of local college teachers' educational technology literacy in view of the problems existing in the training of local college teachers' educational technology.
\end{abstract}

\section{Introduction}

"The biggest challenge facing future education is not technology, not resources, but the quality of teachers." With the continuous advancement of education informatization, modern education technology is booming. Familiar with modern education theory and mastering modern education technology skills will become qualities that teachers must possess in the future. Therefore, in the era of highly developed information technology, teachers' information literacy, especially the application of modern educational technology, is particularly important. The rapid development of information technology has provided the necessary technical support for education informatization. The continuous in-depth education informatization has provided higher working conditions for higher education workers [1]. The role of modern educational technology in college education has become increasingly significant. With the continuous development of modern educational technology theory and technology, more and more new educational theories and teaching media techniques are continuously applied in the teaching process of teachers. The application of these new educational theories and techniques will inevitably break the traditional teaching philosophy. With the model, education is undergoing a profound transformation of educational concepts, educational contents, educational methods, educational methods, educational models, and educational processes. With the continuous improvement of the degree of social informatization in the future, colleges and universities that undertake high-level personnel training urgently require that teachers have the appropriate educational technology application capabilities and continuously improve their own educational and technical qualities. China attaches great importance to the ability of college teachers in the application of educational technology, and puts forward the slogan "modern educational technology is the commanding height and breakthrough point of educational reform". Comrade Chen Zhili repeatedly pointed out: "We must deeply understand the main status and application of modern education technology in education and its urgency; fully understand the application of modern education technology is the requirement of modern science and technology and social development for education. It is education reform. Teachers at all levels and in all types of schools must keep pace with the development of science and technology, and strive to grasp and apply modern educational technology to improve their own quality and to meet the needs of modern 
education." [2]

\section{The Application Status Quo of University Teacher Education Technology}

As early as 1999, the Ministry of Education began to implement modern distance education projects and successively approved 69 colleges and universities for piloting online education. Its purpose is to use modern information technology to accelerate the development of higher education and advance the process of education informatization. In December 2000, the Higher Education Department of the Ministry of Education issued the "Notice on Launching Educational Technology Training for University Teachers” (Teaching Department [2000] No. 79 Document): Education technology is an important means to improve teaching quality and promote quality education. The "educational technology training" is an important part of the "new century education reform project" and "modern distance education project". It is an important measure to deepen teaching reform and improve teaching quality. The Higher Education Department decided to start the training of university teacher education technology from 2001 and entrusted the National Educational Technology Cooperation Committee to organize and implement the training. Our country began to carry out the education technology training for university teachers since 2001. Over the past few years, the National College Educational Technology Cooperation Committee has actively organized the training work, established training work committees, organized training plans and training outlines, and compiled training materials. Gradually establish and improve various rules and regulations for teacher training in institutions of higher learning, such as the training management system, certificate distribution procedures, and assessment methods. Organize and coordinate educational technology training for universities and colleges across the country, authorize qualified universities to set up educational technology training centers, organize training for teachers in training centers of universities, conduct qualifications, and do a lot of work [3].

In 2004, the Peking University Educational Technology Research Center conducted an investigation of the educational hardware and software environment of China's universities and colleges. The results showed that the hardware support environment for college education technology has been quite complete, and the computer ownership ratio of teachers and students in our colleges and universities has reached a high level. The survey statistics show that in terms of hardware environment, the average proportion of teachers in each university has reached 35 . The average proportion of $4 \%$ and 2 - 5 persons is 48. 5\%; Managers are even higher than teachers, with an average of $43.5 \%$ for one person and 45 for two to five people. $8 \%$; In terms of the software environment, teachers currently use $96 \%$ of PPT in classroom teaching. 8\%, the proportion of using computer courseware reached 69. 0\%, using e-mail and BBS to communicate and discuss the proportion accounted for $65.5 \%$ and $19.7 \%$, the proportion of using the Internet for teaching reached $30.5 \%$. In improving teaching, $50 \%$ of teachers often use modern educational techniques to improve teaching. Teachers believe that the application of modern educational technology to improve teaching is multifaceted, such as improving the quality and efficiency of teaching, promoting the development of students' creative thinking, cultivating students' information skills, advancing quality education, and alleviating the workload of teachers.

\section{University Teachers' Educational Technology Ability Training Practice}

In the school-based training of university teacher education technology, the "face to face" training model based on centralized organization should be the main line, supplemented by the collaborative learning model based on the online teaching platform, and the multiple research models based on topic-driven research should be used to build a variety of ideas. The training modes complement each other and complement each other in a comprehensive training model to form a new type of school-based teacher training system [4].

It is to integrate teachers to a certain extent, to conduct hierarchical and systematic "face to face" training, to choose the location of the teaching in the network multimedia classrooms, and to use manpower to teach the teacher while performing real tasks, specific operations, and repeated 
practice. In the course of teaching, Shixun teachers pay more attention to the application of modern educational technology and adopt various teaching methods such as demonstration teaching, group collaboration, case teaching, task-driven, and action research, so that the trained teachers can really feel the charm of educational technology. In the implementation process, it focuses on the system design of the training main line, the teaching design of the single training, etc., and integrates the training of the teachers according to the training objectives, integrating the advocated theories, applied technologies, and research methods into the training process. The advantage of this training model is that the entire training process facilitates the guidance of training teachers and experts, which saves time and money, and combines the teaching practice of the school. The time is not long but the effect is significant. However, because of the same training content and program, this model has the disadvantage of insufficient personalization and does not meet the needs of each teacher.

Collaborative learning model based on online teaching platform. This model is a powerful complement to model (1). We chose the Blackboard e-learning platform as a support tool, built a web-based course, was task-driven, used the interactive features of the platform to organize group collaborative learning, and hired educational technology applications to be very experienced. Disciplinary experts participate in the online instruction and carry out on-line questions and comments with the training teachers on the trainee teachers, which can greatly expand the training's space-time scope, overcome the limitations of teachers' time dispersion and large group differences. At the same time, it is also possible to strengthen the exchanges and cooperation among the trained teachers and have great advantages in achieving individualized learning and collaborative learning. The advantage of this model is that the learning time and learning method are autonomous and flexible, and it is more suitable for the characteristics of college teachers. The disadvantage is that the training organization and management are loose and the efficiency is not high.

It is through organizing teachers to participate in various types of educational technology research topics and actively participating in educational technology research and accepting corresponding issues in the process of "selecting topics-> implementing-> research-> checking-> finalizing-> feedback" of the project. Training and guidance, in the form of research projects and teaching experiments, develops teachers' research abilities, information abilities, problem solving abilities, and collaborative spirits. They constantly reflect on the deficiencies in training and learning, and promote the integration of educational technology and teaching research. The advantage of this model is that it can combine teaching practice with teaching research, and promote the development of teachers' teaching from experience-based to research-based and expert-oriented. However, teachers need to invest a lot of time and energy in this way.

For the evaluation of training, we adopt flexible and diverse evaluation methods, focusing on the combination of process evaluation and summative evaluation. The training teacher's usual learning performance, task completion, and learning papers, electronic works, etc. are combined, and self-evaluation, self-evaluation, teacher evaluation, and expert evaluation organic combination evaluation methods are displayed through the teacher's own work display. In the course of training, experienced experts are invited to work with training instructors to conduct online reviews and on-site comments, and online peer review among student teams [5].

Strengthen the cooperation between the education technology center, the personnel department and the education department, carry out the school-based training of teacher education technology with different levels, types and stages, and adopt the combination of length and length, combination of in-class training and extracurricular instruction, and classroom concentration. The types of training include education and technical level training, project training, expert lectures, excellent teaching resources, research and discussion, and so on, to promote subject teachers to change teaching concepts, to further promote the reform of teaching methods and methods, and to improve the educational technology capabilities and professional qualities of college teachers.

\section{Conclusion}

This article through the investigation and study of some local college teachers on educational technology application ability, found that college teachers in the education and teaching process 
lacks the correct understanding of educational technology theory and application, its ability to use educational technology to assist teaching in education and teaching is extremely limited Therefore, this paper proposes some new ideas for the training of local college teachers' educational technology literacy in view of the problems existing in the training of local college teachers' educational technology. Improving college teachers' modern educational technology literacy will advance education informatization, modernize education, and promote quality. Education, the promotion of reform in education and teaching in institutions of higher education, and the overall improvement of education and teaching quality play an extremely important role.

\section{References}

[1] Wang Hongmei. The Idea of Improving University Teachers' Information Literacy in the Process of Educational Informatization [J]. Guangxi Education, 2010, (10).66

[2] Wang Wei. Foreign teacher information technology application ability standards review [J]. Information Technology Education in Primary and Secondary Schools, 2005, (6).39

[3] Wang Ying, Li Li, Zhu Xiaonan. New foreign teacher education technology ability training research [J]. Information Technology Education, 2006, (3).127

[4] Ke Qingchao. Research on Teacher Education Technology Ability Training Model for Mixed Learning [J]. Electrification Education Research, 2008, (2).58

[5] Zhou Hongchun. Teacher education technology ability cultivation under the information environment [J]. Modern Educational Technology, 2010, (6).63 